\title{
DIGLOSIA
}

Volume 1, Nomor 2 (Agustus 2018)

ISSN 2615-725X (Print)

Halaman 53-64

eISSN 2615-8655 (Online)

\section{CERITA ANAK SEBAGAI MEDIA PEMBENTUK KARAKTER ANAK}

\author{
Ferdian Achsani \\ Tadris Bahasa Indonesia \\ Institut Agama Islam Negeri Surakarta \\ Pos-el: dwikurniawan219@gmail.com
}

\begin{abstract}
Literature and character education are two things that can not be separated. Literature as a reflection of the life of the community, generally teaches the reader to be able to understand the wisdom of the displayed story. Literature can be used as a medium of learning, especially in the process of internalization of the value of character education to learners. The value of character education in the literary work is expected to be followed by the students. Currently Indonesia is experiencing moral degradation. The need for moral cultivation to the learners aims to create buman beings who are virtuous in the future. Each subject has the right to internalize character education to learners. So in the Indonesian language, the process of characterization of character education can be done when learning on literary materials. This study aims to describe the value of character education in Solopos children's stories. this research is included in qualitative discrptive research. The results of this study concluded that in the story Solopos child, there is a value of character education that can be taught to learners, especially at elementary school level. The results showed that this child's story can be used as a reference for teachers, as a medium to internalize character education at elementary school level.
\end{abstract}

Keywords: character education, children's story, learning media

\begin{abstract}
ABSTRAK
Sastra dan pendidikan karakter merupakan dua hal yang tidak dapat dipisahkan. Sastra sebagai cerminan kehidupan masyarakat, umumnya mengajarkan kepada pembaca untuk dapat memahami hikmah dari cerita yang ditampilkan. Sastra dapat digunakan sebagai media pembelajaran, terutama dalam proses penginternalisasian nilai pendidikan karakter kepada peserta didik. Nilai pendidikan karakter dalam karya sastra tersebut diharapkan dapat diteladani oleh peserta didik. Saat ini Indonesia sedang mengalami degradasi moral. Perlunya penanaman moral kepada peserta didik bertujuan untuk menciptakan manusia yang berbudi pekerti di masa depan. Setiap mata pelajaran memiliki hak untuk menginternalisasikan pendidikan karakter kepada peserta didik. Maka dalam bahasa Indonesia, proses penginternalisasian pendidikan karakter dapat dilakukan ketika pembelajaran pada materi kesastraan. Penelitian ini bertujuan untuk mendiskripsikan nilai pendidikan karakter dalam cerita anak Solopos. penelitian ini termasuk dalam penelitian diskrptif kualitatif. Hasil penelitian ini menyimpulkan bahwa dalam cerita anak Solopos, terdapat nilai pendidikan karakter yang dapat diajarkan kepada peserta didik terutama pada jenjang sekolah dasar. Hasil penelitian menunjukan bahwa cerita anak ini dapat digunakan sebagai rujukkan bagi guru, sebagai media untuk menginternalisasikan pendidikan karakter pada jenjang sekolah dasar.
\end{abstract}

Kata kunci: pendidikan karakter, cerita anak, media pembelajaran 


\section{A. PENDAHULUAN}

Pendidikan tidak hanya bertujuan untuk membentuk ranah kognitif peserta didik, namun juga bertujuan untuk membentuk karakter peserta didik. Hal ini sesuai dengan amanat UU Sidiknak nomor 20 Tahun 2003 Pasal 3 yang menyebutkan bahwa pendidikan nasional berfungsi untuk mengembangkan dan membentuk watak serta peradaban bangsa yang martabat dalam rangka mencerdaskan kehidupan bangsa. Akan tetapi, peserta didik kurang memahami arti penting dari pendidikan yang demikian sehingga banyak peserta didik yang beranggapan bahwa pendidikan hanyalah suatu proses transfer ilmu pengetahuan yang di berikan oleh guru kepada peserta didik.

Akibatnya, siswa seolah berfikir bahwa guru tidak ada hak untuk mengatur tingkah laku mereka. Padahal peran guru dalam pembentukkan karakter peserta didik sangatlah besar. Memang, Selain guru, peran orang tua jauh lebih besar dalam pembentukkan karakter siswa. Hal ini disebabkan karena siswa lebih banyak menghabiskan waktu di keluarga (rumah) daripada disekolah. Jadi orang tua lebih memiliki peluang besar untuk membentuk karakter anak.

Akan tetapi, dewasa ini orang tua seakan lalai dalam tugas pentingnya tersebut. Orang tua seakan lepas terhadap perkembangan dan tanggung jawab terhadap perilaku anak-anak mereka sehingga terjadilah degradasi moral pada diri anak-anak. Ketika anak mengalami degradasi moral, mereka memiliki sikap membangkang sehingga peran guru untuk membentuk karakter siswa sudah tidak ada gunanya. Lickona (2013)—yang dikenal sebagai bapak pendidikan karakter-menyatakan bahwa tidak membekali generasi muda dengan pemahaman moral adalah sebuah kegagalan etis serius dari masyarakat.

Pendidikan karakter bukan mata pelajaran tambahan. Pelaksanaan pendidikan karakter dapat diintegrasikan dalam setiap proses pembelajaran yang dilakukan guru. Semua mata pembelajaran berperan penting dalam proses penginternalisasian nilai pendidikan karakter. Proses internalisasi nilai-nilai pada peserta didik tidak dapat dilakukan secara cepat dan tiba-tiba (Damayanti, 2014). Perlu adanya penyesuaian dan waktu yang relatif lama untuk membentuk karakter peserta didik. Artinya, penginternalisasian nilai-nialai pendidikan karakter dilakukan secara bertahap dan dan tidak bisa dilakukan secara isntant. Pengajaran pendidikan karakter dilakukan melalui kebiasaan. Untuk itu pendidikan karakter perlu diajarkan kepada anak mulai dari jenjang PAUD sampai Perguruan Tinggi, dengan tujuan agar bekal pendidikan karakter pada anak dapat terpupuk sejak dini.

Dalam proses penginternalisasian pendidikan karakter pada siswa melalui pemebelajaran, diperlukan metode dan media yang cocok agar proses tersebut dapat berjalan dengan sempurna. Pada pembelajaran bahasa Indonesia, Salah satunya yaitu Melalui cerita anak. cerita anak dapat digunakan oleh guru maupun orang tua untuk mengajarkan pendidikan karakter kepada anak-anak ketika masih kecil. Hasil akhir dari membaca cerita anak adalah anak akan merasa senang, puas dan mampu memperoleh pelajaran berharga (Nurgiyantoro, 2013:219). Cerita anak dapat dikategorikan sebagai karya sastra yangmana Setiap karya sastra memiliki nilai pendidikan karakter yang dapat dijadikan teladan dalam kehidupan seharihari. Nilai-nilai didik tersebutlah yang ingin disampaikan pengarang kepada pembaca sebagai proses mendidik.

Melalui ceita anak proses penginternalisasian pendidikan karakter dengan mudah dilakukan disekolah dan dirumah. Penggunaan cerita anak sebagai media pembelajaran disekolah, dapat dilakukan melalui pembelajaran bahasa 
Indonesia. Sedangkan ketika dirumah, orang tua dapat memberikan cerita anak sebagai bahan bacaan kepada anak.

Melalui penggunaan cerita anak sebagai media pembelajaran, orang tua dan guru dapat bekerjasama secara langsung. Seiring perkembangan teknologi, untuk mengakses cerita anak dapat dengan mudah kita dapatkan oleh anak. Namun orang tua dan guru harus selalu mendampingi anak atau siswa ketika mereka mengakses internet. agar anak tidak menyalahgunakan internet. Untuk itu orang tua dan guru harus beralih dari internet dan mulai kreatif mencarikan cerita anak yang cocok untuk siswa. Salah satunya, dengan cerita anak yang dapat ditemukan dalam koran Solopos yang terbit setiap hari minggu.

Penelitian yang dilakukan oleh (Suhardi, 2018) yang dimuat dalam jurnal lingua volume 14 dapat dijadikan rujukan sebagai penelitian ini. Namun dalam penelitian yang dilakukan oleh suhardi hanya sekadar menguraikan bentuk nilai pendidikan karakter dalam dongeng Putra Lokan. Suhardi tidak menguraikan bagaimana relevansi dongeng tersebut dalam pembelajaran. Berdasarkan hasil penelitian yang dilakukan oleh Suhardi, guru dan orang tua dapat memanfaatkannya sebagai media pembelajaran. Dari penelitian yang dilakukan suhardi tersebut, penulis tertarik untuk menguraikan bagaimana bentuk nilai pendidikan karakter dalam cernak Solopos edisi bulan maret 2018, serta bagaimana relevansinya terhadap pembelajaran dalam lingkungan sekolah maupun di lingkungan keluarga.

\section{B. LANDASAN TEORI}

\section{Pendidikan karakter}

Pada hakikatnya, karakter merupakan pengajaran tentang hal-hal yang dianggap baik bagi seseorang. karakter mengacu kepada perilaku yang sesuai dengan norma agama, sosial dan budaya yang berlaku dalam kehidupan masyarakat. Untuk itu pendidikan karakter dapat dimaknai sebagai suatu proses pengajaran atau tuntunan mengenai hal yang baik dan buruk kepada peserta didik. Dengan adanya pendidikan karakter, dapat menjadikan peserta didik yang berkarakter demi menyongsong generasi yang akan datang. Wiyani (2013: 28) menyatakan bahwa Pendidikan karakter dapat dimaknai sebagai pendidikan nilai, penididkan budi pekerti, pendiidkan moral, pendidikkan watak, yang bertujuan untuk membeirkan keputusan baik-buruk, memelihara apa yang baik, dan mewujudkan kebaikan dalam kehidupan sehari-hari dengan sepenuh hati.

Pendidikan karakter bukanlah mata pelajaran khusus yang diajarkan di sekolah. namun pendidikan karakter merupakan proses pengajaran nilai-nilai yang diinternalisasikan ke dalam proses pembelajaran dalam semua mata pelajaran. Untuk itu dalam pidato yang disampaikan oleh mentri pendidikan, Muhadjir Effendi (2017) menyatakan bahwa guru sebagai pokok utama dalam satuan pendidikan mereka memiliki tanggung jawab untuk membentuk karakter peserta didik melalui harmonisasi olahraga, olah rasa, olah hati, dan olah pikir. Selama proses pembelajaran berlangsung guru berperan dalam pembentukan karakter peserta didik. Maka disinilah letak semboyan pendidikan "Ing ngarsa sung tuladha, ing madya mangun karsa, tut wuri bandayani" yang memiliki arti bahwa guru di depan memberi contoh, di tengah memberi semangat dan di belakang memberikan dorongan.

Tanpa nilai-nilai kebijakan yang membentuk karakter yang baik, individu tidak bisa hidup bahagia dan tidak ada masyarakat yang dapat berfungsi secara efektif (Lickona, 2016: 22). Maka, demi membentuk peserta didik yang berkarakter, Depdiknas mengemukakan 18 pilar nilai-nilai pendidikan karakter yang harus ditanamkan dalam diri setiap peserta didik. Delapan belas pilar tersebut 
adalah: Jujur, Toleransi, Disiplin, Kerja keras, Kreatif, Mandiri, Demokratis, Rasa Ingin Tahu, Semangat Kebangsaan, Cinta Tanah Air, Menghargai Prestasi, Bersahabat/Komunikatif, Cinta Damai, Gemar Membaca, Peduli Lingkungan, Peduli Sosial, Tanggung Jawab, dan Religious. Pilar-pilar pendidikan karakter tersebut bersumber dari ajaran agama, pancasila, dan norma maupun adat yang sudah berkembang dan membudidaya di masyarakat.

\section{Sastra anak}

Sastra anak merupakan sebuah karya tulis yang mengisahkan runtutan kehidupan manusia dengan tokoh utama anak-anak. Pembaca lebih yang di tujukan kepada anak-anak untuk pembelajaran kepada mereka. Sudut pandang kisah pun menceritakan tentang kehidupan anakanak. Namun tidak dapat dipungkiri bahwa orang dewasa juga banyak menikmati sastra anak.

Faisal (dalam Rukhayah, 2015:31) mengungkapkan bahwa sastra anak adalah karya sastra (prosa, puisi, drama) yang isinya mengenai anak-anak, sesuai dengan kehidupan, kesenangan, sifat-sifat dan perkembangan anak. Cerita dalam Sastra anak umumnya lebih mencerminkan kisah yang memotivasi anak untuk melakukan kebaikan. Kisah hidup yang ditampilkan oleh tokoh dalam cerita anak, dapat memengaruhi psikologi perilaku anak. Anak dapat memahami dan belajar tentang berbagai aspek kehidupan lewat apa yang diperankan oleh tokoh tersebut, termasuk berbagai motivasi yang dilatari oleh keadaan sosial budaya tokoh itu (Nurgiyantoro, 2010).

Misalnya, ketika anak membaca atau mendengar cerita bawang merah bawang putih tentu anak akan merasa benci dengan tokoh bawang merah yang selalu berbuat jahat kepada bawang putih sehingga Melalui cerita bawang merah bawang putih tersebut, dapat mempengaruhi psikologi anak. anak akan mudah benci terhadap perilaku bawang merah (jahat) dan mencintai perilaku bawang putih (kebaikan).

Lukens (dalam Nurgiyantoro, 2013:15) mengelompokkan genre sastra anak ke dalam enam macam, yaitu realisme, fiksi formula, fantasi, sastra tradisional, puisi dan nonfiksi. Seluruh cerita anak tersebut memiliki satu tujuan yaitu untuk membentuk karakter anak agar menjadi insan yang berbudi pekerti luhur.

Kaitannya dengan pembelajaran, sastra anak dapat digunakan sebagai media pembelajaran dalam mata pelajaran bahasa Indonesia. Nilai-nilai karakter yang disampaikan dalam sastra anak, dapat digunakan guru sebagai media pembelajaran yang tepat bagai siswa sekolah dasar. Sastra dan bahasa merupakan kesatuan yang tidak dapat untuk dipisahkan. Sastra merupakan bagian dari hasil olah bahasa. Maka dari itu, pembelajaran bahasa Indonesia tidak dapat dipisahkan dengan sastra.

\section{METODE PENELITIAN}

Penelitian ini merupakan penelitian sastra, dimana objek kajiannya adalah cerita anak dalam harian Solopos edisi Januari-Maret, yang terbit setiap hari minggu. Penelitian ini termasuk dalam jenis penelitian kualitatif. Hal ini di karenakan sumber data dalam penelitian ini berupta teks. Sesuai dengan pengertiannya bahwa penelitian kualitatif adalah penelitian yang mendiskripsikan, gambar, tulisan, dll. Adapun teknik pengumpulan data dalam penelitian ini, pertama mengumpulkan objek kajian, setelah seluruh data terkumpul, peneliti membaca objek penelitain. Langkah terakhir adalah penarikkan data dan kesimpulan. Teknik analisis dalam penelitian ini adalah analisis konten. 


\section{HASIL PENELITIAN}

\section{Bentuk Pendidikan Karakter a. Religious}

Religious merupakan suatu sikap yang mencerminkan seseorang untuk selalu taat menjalankan perintah Tuhan YME. Karakter religious dalam cerita anak Solopos ini dapat dilihat melalui kutipan berikut.

"pamit dulu, Bu. mau berburu

Kinjeng. Assalamu'alaikum" pamit Nana dia akan bersiap ke rumah Tutik (Latifah, 2018).

Kutipan di atas merupakan cerminan dari karakter religious. Agama Islam mengajarkan untuk mengucapkan salam ketika hendak pergi, atau datang ke pada siapapun, karena mengucapkan salam termasuk dalam ibadah. Dalam kutipan tersebut, Nana mengucapkan salam kepada Ibunya. Melalui kutipan tersebut dapat kita ambil pembelajaran bahwa mengucapkan salam merupakan salah satu contoh dari bentuk karakter religious.

\section{b. Jujur}

Suatu sikap atau tindakkan yang menuntut seseorang agar selalu bersikap apaadanya tanpa mengecwakan oranglain. Kutipan karakter jujur dalam cerita anak Solopos terdapat pada data berikut ini.

$$
\begin{aligned}
& \text { Ia pun akhirnya mengakui } \\
& \text { perbuatannya dan setuju menghadap } \\
& \text { Bu Zaida dan kepala sekolah. beni } \\
& \text { meminta maaf atas perbuatannya dan } \\
& \text { berjanji tidak akan mengulanginya lagi. } \\
& \text { (Pena, 2018). }
\end{aligned}
$$

Kutipan di atas merupakan karakter jujur yang di tampilkan oleh tokoh Beni dalam cerita anak berjudul Prestasi Nadia. Suatu ketika, nilai ulangan yang didapatkan oleh Beni lebih tinggi daripada nilai yang didapatkan oleh Nadia. Namun, nilai yang diperoleh bukan karena hasil kerja kerasnya sendiri namun karena ia mencontek. Akhirnya Nadia memberanikan diri untuk menemui Beni dan meminta Beni agar ia selalu berbuat jujur dan mengakui perbuatannya bahwa yang ia lakukan adalah salah dan tidak benar. Melalui kutipan tersebut kita dapat mengambil pembelajaran bahwa kejujuran merupakan suatu hal mutlak untuk memperoleh keberhasilan.

\section{c. Tanggung jawab}

Tanggung jawab merupakan suatu sikap untuk bisa melaksanakan kewajibannya. Karakter tanggung jawab dalam cerita anak koran Solopos, dapat dilihat melalui kutipan berikut ini.

$$
\begin{aligned}
& \text { Rizal dan ketiga temannya, Hasan, } \\
& \text { Rudi, dan Akbar, selalu membantu } \\
& \text { orang tua mereka di kebuh seusai } \\
& \text { sekolah (Tarra, 2018). }
\end{aligned}
$$

Kutipan tanggung jawab tersebut terdapat pada cerita anak berjudul Empat Sekawan dari Kampung Kelapa. Dalam kutipan tersebut menceritakan bahwa tokoh Rizal, Rudi, Hasan dan Akbar merupakan pribadi yang patuh kepada orang tua. Hal itu dibuktikan dengan setiap pulang sekolah mereka selalu membantu ayahnya di kebun kelapa. Hal ini dapat di katakan bahwa perbuatan Rizal, Rudi, Hasan dan Akbar merupakan wujud dari rasa karakter tanggung jawab. Sebagai seorang siswa, ia memiliki kewajiban untuk belajar dan membantu orang tua. Karakter tanggung jawab yang lain mengenai membantu orang tua juga dapat dilihat dalam kutipan berikut ini.

Nyaris setiap hari libur khususnya minggu, Boni dan Uni memang membantu ayah mengurus ladAng (Rositi, 2018).

Kutipan di atas juga mencerminkan karakter tanggung jawab sebagai wujud bakti anak terhadap orang tua. Kutipan yang terdapat dalam cerita Ayo Biasakan Mencuci Tangan tersebut, mengajarkan kepada pembaca untuk membantu kedua orang tua dalam segala hal. Melalui dua kutipan tersebut pembaca dapat 
mengambil pembelajaran, bahwa salah satu wujud karakter yang tampak dalam cerita anak koran Solopos adalah membantu orang tua, karena hal tersebut merupakan kewajiban seorang anak, sekaligus sebagai tanda bakti anak terhadap orang tua.

\section{d. Demokratis}

Demokratis merupakan Suatu sikap yang selalu bertindak untuk menghargai pendapat orang lain, dan tidak mementingkan diri atau ego sendiri. Dalam cerita anak Solopos, karakter demokratis dapat dilihat melalui kutipan berikut ini.

Akhirnya setelah musyawarah dengan warga lain, Pak Badrun dimaafkan dengan syarat tidak mengulangi lagi perbuatannya (Tarra, 2018).

Kutipan tersebut terdapat pada cerita Empat Sekawan Dari Kampung Kelapa. Dalam kutipan tersebut menceritakan kejadian setelah pencuri kelapa di kampong suka maju tertangkap. Setelah mengetahui bahwa pencuri kelapa di kampong suka maju adalah Pak Badrun, ayah Rizal mengajak musyawarah kepada masyarakat sekitar untuk memaafkan kesalahan Pak Badrun. Musyawarah merupakan suatu kegiatan yang bertujuan untuk mencapai kesepakatan bersama tanpa harus memetingkan ego sendiri. musyawarah dapat dikatakan sebagai salah satu contoh karakter demokratis, karena dalam musyawarah kesepakatan berada di tangan seluruh yang hadir dan tidak hanya mengikuti pendapat seseorang (golput). Wujud karakter demokratis tentang musyawarah yang lain dapat dilihat dalam kutipan berikut.

\footnotetext{
"baiklah, kalau begitu kita mulai saja pemilihannya. Kita akan memakai cara voting. Siapa nanti yang mendapat suara terbanyak dialah yang menjadi ketua kelas," kata Bu Guru (Romadhon, 2018).
}

Kutipan tersebut terdapat pada cerita anak berjudul Kado Imlek Mee Lan. Dikarenakan Yosep harus pindah sekolah, dari sekolah Bhineka ke Papua, maka posisi nya sebagai ketua kelas pun harus tergantikan. Bu Ratri sebagai wali kelas, menunjuk salah satu dari Salim, Titis, Soetono dan Mee Lan untuk menjadi ketua kelas. Pemilihan ketua kelas dilakukan secara voting. Hasil voting menunjukkan bahwa Mee Lan mendapat voting tertinggi dan ia pun berhak menjadi ketua kelas. Voting merupakan salah satu cara yang digunakan untuk mengumpulkan suara dan jugat termasuk dalam bagian musyawarah. Suara terbanyak dalam voting adalah pemenanganya atau hasilnya. Voting dan musyawarah merupakan dua hal yang mencerminkan karakter demokrasi. Melalui dua kutipan tersebut dapat diambil pelajaran bahwa dalam meyimpulkan pendapat orang yang berbeda-beda dapat dilakukan dengan voting dan musyawarah.

\section{e. Bersahabat}

Bersahabat mencerminkan suatu sikap untuk bisa bersosialisasi terhadap orang lain, tanpa membedakan ras, suku dan agama. Wujud pendidikan karakter karakter bersahabat dapat dilihat melalui kutipan berikut.

$$
\begin{aligned}
& \text { "tentu saja. Kita ini, kan, empat } \\
& \text { sekawan dari kampong kelapa." } \\
& \text { Akbar merangkul Rudi dengan erat, } \\
& \text { diikuti Rizal dan Hasan (Tarra, 2018). }
\end{aligned}
$$

Setelah mengetahui bahwa ayahnya adalah pencuri kelapa selama ini, Rudi merasa malu. Ia takut jika Rizal, Hasan dan Akbar tidak ingin lagi berteman dengannya. Namun, baik Rizal, Hasan maupun Akbar masing-masing tidak memiliki niatan buruk untuk mengucilkan Rudi. justru mereka malah ingin tetap berteman dengan Rudi. kutipan tersebut mencerminkan bahwa bersahabat itu tidak harus pandang bulu. Sebagai makhluk sosial sudah seharusnya kita saling 
berteman dengan yang lain. Karakter bersahabat yang lain juga dapat dilihat dalam kutipan berikut.

$$
\begin{aligned}
& \text {...Jadi Mee Lan yang terpilih } \\
& \text { menjadi ketua kelas. Salim, titis dan } \\
& \text { soetono memberikan ucapan selamat } \\
& \text { kepada mee lan (Romadhon, 2018). }
\end{aligned}
$$

Setelah Mee Lan terpilih menjadi ketua kelas, baik Salim, Titis dan Soetono tidak ada yang iri terhadapnya. Mereka justru senang karena Mee Lan lah yang terpilih menjadi ketua kelas. Sebagai bentuk persahabatan, mereka mengucapkan selamat, dan saling berjabat tangan kepadanya.

\section{f. Kreatif}

Kreatif merupakan suatu sikap berfikir, yang dapat menciptakan hal-hal baru dan berguna bagi masyarakat. Karakter kreatif dalam cerita anak Solopos dapat dilihat dalam kutipan berikut ini.

"Bu Linda dan Rindi, sekarang kan lagi musim penghujan. Tadi saya kan lupa bawa payung. Jadi kantong plastic ini akan saya buat untuk membungkus tas saya. Jadi kalau nanti saya aps pulang tiba-tiba hujan turun, saya akan memasukan sepatu dan tas saya ke dalam kantong plastic ini. Dengan begitu, buku-buku dan sepatu saya tidak akan basah" jawab Asti (Kristanto, 2018).

Pada waktu jam istirahat sekolah, Asti dan Rindi diminta oleh Bu Guru untuk membersihkan dan menata buku di perpustakaan. Setelah selesai membersihkan perpustakaan, karena lupa membawa paying Asti meminta kantung plastic yang sudah tidak dipakai di pakai dan akan di buang oleh Bu Guru untuk ia gunakan sebagai pelindung tas dan sepatunya jikalau hujan turun ketika ia pulang sekolah nanti. Melalui kisah Asti dan Rindi ini dapat kita ambil pembelajaran mengenai karakter kreatif. Barang-barang yang sudah tidak terpakai, sebenarnya masih dapat untuk kita manfaatkan atau kita gunakan kembali. Semua itu tergantung pada diri kita masing-masing. Karakter kreatif yang lain juga dapat dilihat dalam kutipan berikut ini.

"siapa bilang enggak seru. Lompat karet bisa kok dilakukan dua orang saja. Bagian satu diikat ke pohon dan bagian satunya kakak yang pegang. Nanti kamu yang main. Sekarang kamu bantuin kakak buat menyampung karet gelang ini satu per satu" (Endah, 2018).

Ratna dan Menik, adalah dua saudara kakak beradik. Kebiasaan buruk Menik yang selalu bermain game online, membuat Ratna penasaran. Gara-gara ratna banyak bertanya kepada Menik, akhirnya Menik kalah dalam permainan itu dan marah kepada Ratna. Ratna pun merasa bersalah. Sebagai penebus kesalahannya tersebut, Ia pun mengajak menik untuk bermain lompat tali. Akan tetapi, mereka hanya berdua, dan butuh satu orang lagi untuk memegang tali. Namun, Ratna memiliki ide untuk mengikat tali satunya ke batang pohon, sedangkan tali satunya dipegang. Hal tersebut merupakan sikap karakter kreatif yang ditampilkan oleh Ratna, bahwa Bermain lompat tali bisa dilakukan dengan dua orang tanpa harus dilakukan dengan tiga orang.

\section{g. Peduli Sosial}

Peduli sosial merupakan sikap yang mendorong individu untuk ikut merasakan apa yang dirasakan orang lain sehingga kita memiliki perasaan untuk membantu orang tersebut. Dalam cerita anak Solopos, yang menceritakan mengenai sikap peduli sosial dapat dilihat dalam kutipan berikut.

\footnotetext{
"sama-sama aku juga terima kasih karena kamu telah berkenan membagi payung kamu" (Kristanto, 2018).
}

Dalam kutipan di atas mencerminkan karakter untuk saling tolong menolong. Ketika pulang sekolah, hujan pun turun. 
Dikarenakan Rindi lupa membawa payung, Asti pun berbagi payung dengan Rindi ketika pulang sekolah. Mereka jalan kaki sambil memegang plastic dan payung rindi. Sikap tolong menolong dalam kutipan tersebut menggambarkan bahwa sesama manusia sudah sewajarnya kita saling tolong menolong dengan orang yang membutuhkan. Karakter tolong menolong yang lain juga dapat dilihat dalam kutipan berikut ini

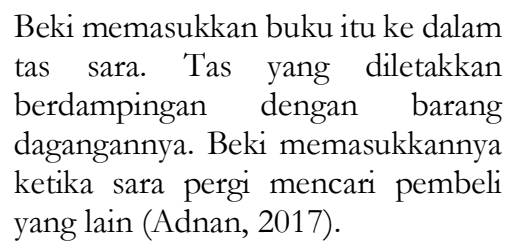

Sara merupakan anak yang kurang mampu dari segi ekonomi. Suatu ketika ia ingin membeli buku, tetapi ia tidak mempunyai uang. Beki menjadi iba ketika melihat sara berjuang mengumpulkan uang untuk membeli buku. Akhirnya ia mempunyai ide untuk memberikan buku kepada sara. Melalui karakter tolong menolong ini, pembaca dapat mengambil hikmah bahwa sebagai makhluk sosial, manusia akan saling membutuhkan satu dengan yang lainnya. Jadi sudah sewajarnya mereka untuk saling tolong menolong dalam keadaan apapun. sikap peduli pada dua kutipan di atas patut dicontoh dan diteladani oleh anak-anak.

\section{h. Disiplin}

Disiplin merupakan karakter yang mencerminkan patuh terhadap peraturan ataupun tata tertib. Dalam cerita anak Solopos, karakter disiplin dapat ditampilkan melalui kutipan berikut ini.

\footnotetext{
"Aku kapok aku tidak akan ceroboh lagi. Iya aku akan membiasakan diri untuk selalu hidup sehat, mencuci tangan sebelum makan, juga tidak lupa berdoa" ucap Boni saat baru sadar (Rositi, 2018).
}

Salah satu hal yang paling disukai oleh Boni ketika membantu Ayahnya di ladang, adalah ketika ia bisa menikmati makan siang di bawah pohon sambil melihat pemandangan alam. Namun karena Kebiasaan Boni yang ceroboh, ia selalu makan tanpa mencucui tangan sehingga membuat perutnya sakit dan jatuh pingsan . melalui kutipan tersebut pembaca dapat mengambil kesimpulan bahwa sebelum makan, kita harus selalu menjaga kebersihan terutama, terutama mencuci tangan sebelum makan agar kumankuman tidak masuk ke dalam tubuh hingga membuat tubuh kita sakit.

$$
\begin{aligned}
& \text { "Sena, kita berangkat dulu ya," } \\
& \text { pamit yusuf dan teman yang lain. } \\
& \text { "lah kalian kenapa berangkat dulu? } \\
& \text { Aku masih belum mandi," sahut sena. } \\
& \text { (Achmad, 2018) }
\end{aligned}
$$

Kutipan di atas mencerminkan karakter disiplin tepat waktu. Dalam cerita anak berjudul Gara-Gara Layangan, menceritakan tokoh Sena yang suka menunda-nunda pekerjaan dalam segala hal. Hingga Suatu ketika, Pak Kamto dan Ibu Fatimah menyuruh Sena untuk berangkat mengjai. Naum karena ia melihat layangan yang putus, ia pun bergegas untuk mengejarnya dan menunda untuk berangkat mengaji. Bukannya mendapatkan layangan, ia justru malah ditinggal berangkat mengaji oleh teman-temannya. Melalui kutipan tersebut dapat diambil pembelajaran bahwa karakter disiplin salah satunya dapat dilakukan dengan tidak menunda waktu maupun pekerjaan.

\section{i. Peduli Lingkungan}

Peduli lingkungan merupakan karakter yang mengajarkan untuk mencintai lingkungan sekitar. karakter tentang peduli lingkungan dapat dilihat dalam Kutipan berikut ini.

"kamu pasti tidak senang jika dikurung bukan? Tidak mau pisah dengan keluarga? Nah begipula Kinjeng” (Latifah, 2018). 
Nana dan Tutik mempunyai Kebiasaan, ketika pulang sekolah, mereka selalu berburu kinjeng yang berada di pekarangan belakang masjid. Suatu hari Tutik, ingin berburu kinjeng emas dan ingin memeliharanya di Rumah. Namun niat itu sirna ketika Nana menasihati Tutik bahwa rumah makhkluk hidup terutama kinjeng itu adalah di alam bebas. Tidak seharusnya Tutik memeliharanya di rumah. Melalui kisah berburu kinjeng, pembaca dapat mengambil pendidikan karakter tentang peduli lingkungan, bahwa makhluk hidup adalah ciptaan tuhan dan harus tetap dijaga. Selain itu melalui cerita tersebut dapat menambah pelajaran baru tentang menghargai makluk hidup dan terus melestarikannya.

\section{j. Cinta Tanah Air}

Cinta tanah air merupakan sikap bangga pada diri sendiri, rela berkobran, dan mencintai spenuh hati terhadap bangsa dan Negara. Dalam cerita anak Solopos, karakter cinta tanah air dapat dilihat melalui kutipan berikut.

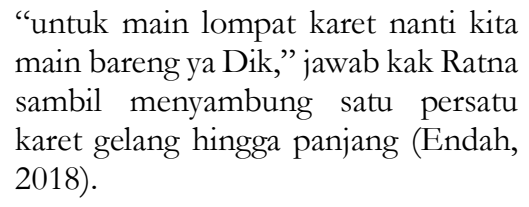
main bareng ya Dik," jawab kak Ratna sambil menyambung satu persatu karet gelang hingga panjang (Endah, 2018).

Salah satu bentuk cinta tanah air adalah dengan mencintai produk-produk dalam negeri. Kutipan di atas menggambarkan karakter cinta tanah air, yang ditunjukkan dengan mencintai permainan tradisional. Permainan tradisional seperti lompat tali, kini sudah jarang dipermainkan oleh anak-anak. melalui kutipan tersebut, dapat kita ambil bahwa Indonesia merupakan Negara yang kaya akan permainan tradisional, yang harus terus di lestarikan sebagai bentuk keragaman budaya.

\section{Relevansi Cerita Anak sebagai Media Pembelajaran \\ a. Lingkungan Sekolah}

Keberhasilan suatu materi yang disamapiakn agar dapat dicapai oleh siswa, tidak luput dari peran media pembelajaran yang digunakan oleh guru. Media pembelajaran dapat diartikan sebagai alat peraga yang digunakn guru dalam menyampaikan pesan materi yang diajarkan untuk mempermudah siswa dalam memahami materi yang disampaikan. Untuk itu Sadiman (2014:7) mendefinisikan bahwa media merupakan segala sesuatu yang dapat digunakan untuk menyalurkan pesan dari pengirim ke penerima sehingga dapat mmerangsang pikiran, perasaan, perhatian dan minat serta perhatian siswa sedemikian rupa sehingga proses belajar terjadi. Dengan adanya media pembelajaran, diharapkan tidak adanya hambatan selama proses pembelajaran.

Penggunaan alat sebagai media pembelajaran, harus disesuaikan dengan materi yang disampaikan, dan jenjang kelas yang diajar. Penggunaan cerita anak dalam koran Solopos ini dapat digunakan sebagai media pembelajaran bahasa indoensia, khususnya dalam materi sastra. Cerita anak dapat digunakan sebagai media pembelajaran siswa sekolah dasar kelas 4 pada KI-KD. 3.9 mencermati tokoh-tokoh yang terdapat pada teks fiksi dan 4.9. menyampaikan hasil identifikasi tokoh-tokoh yang terdapat dalam teks fiksi secara lisan, tulis dan visual. Melalui KI-KD tersebut, penggunaan cerita anak dapat dimanfaatkan seebagai media pembelajaran.

Pada hakikatnya sastra merupakan alat untuk mendidik. Nilai-nilai moral dalam sastra tersebutlah yang digunakan untuk mendidik pembaca. Ismawati (2013: 103-104), menyatakan bahwa Penggunaan cerita anak sebagai media pembelajaran bagi anak hendaknya harus memerhatikan aspek intelektual, aspek emosional, aspek kemampuan berbahasa anak dan struktur 
organisasi isi bacaan. Keempat aspek tersebut harus disesuaikan berdasarkan usia ataupun jenjang siswa. Hal ini diharapkan agar cerita yang disampaikan mudah dimenegerti dan di pahami oleh siswa sehingga mereka dapat menghayati apa yang di sampaikan dalam cerita tersebut.

Alasan penggunaan cerita anak sebagai media pembelajaran, dikarenakan agar pembelajaran tidak hanya terpaku pada buku paket ataupun buku pegangan siswa. Dengan memberikan media pembelajaran yang lain, diharapkan dalam penyampaian materi siswa akan lebih mudah untuk memahaminya. Selain itu, pendidikan karakter yang terdapat pada cerita anak Solopos, diharapkan dapat diajdikan contoh dan teladan bagi peserta didik khususnya siswa sekolah dasar.

Pada praktiknya, siswa akan dibagi menjadi beberapa kelompok. Guru akan membangikan setiap cerita anak kepada amsing-masing kelompok tersebut. setelah itu setiap kelompok diminta untuk mendiskusikan mengenai perilaku yang di tampilkan oleh tokoh-tokoh yang terdapat dalam cerita. Langkah terakhir dalam pembelajaran, siswa diminta untuk menyampaikan ahsil diskusi mereka didepan kelas.

Selama proses pembelajaran, baik berdiskusi maupun dalam proses presentasi, siswa akan mampu untuk memahami mengenai karakter baik dan buruk yang ditampilkan oleh tokoh. Tak lupa, guru juga memberikan penguatan terhadap setiap amanat yang disampaiakn dalam cerita anak tersebut. guru berinteraksi dengan siswa dengan cara menghubungkan perilaku dalam tokoh cerita anak, ke dalam kehidupan seharihari siswa.

Tidak hanya digunakan dalam pembelajaran berlangsung, guru dapat meminta siswa untuk mencari cerita anak sebagai pekerjaan rumah, kemudian guru meminta siswa untuk menceritakan hasil dari cerita yang mereka cari. Jika kebiasaan baik seperti ini terus diterapkan, maka akan memberikan manfaat positif bagi tumbuh kembang mental anak, bahkan memberikan pengaruh yang baik bagi kehidupannya di masa depan (Habsari, 2017). Siswa akan mampu untuk memahami bahwa dalam berperilaku, kita dituntut untuk berkarakter yang baik.

\section{b. Lingkungan keluarga}

Banyak yang berpendapat bahwa pembentuk karakter anak yang paling utama adalah sekolah. namun, ketika guru memberikan pengajaran kepada anak, anak justru marah dan mengadu kepada orang tua sehingga terjadi perselisihan antara orang tua dengan guru. Jika terjadi kasus seperti ini, terletak pada siapakah kesalahannya?

Anggapan bahwa pembentuk karakter anak sepenuhnya adalah tanggungjawab sekolah harus kita tepis mulai dari sekarang. Sekolah hanya berperan sebagai penanaman nilai-nilai pendidikan karakter. Selanjutnya siswa harus mengembangkannya sendiri. Bukan hanya sekolah yang memiliki peran untuk membentuk anak berkarakter. Namun, keluarga juga paling bertanggung jawab untuk menanamkan karakter bagi anak. sebagaimana yang disamapiakn oleh ustad wijayanto (2016), bahwa Keluarga merupakan sekolah utama bagi anak. salah satu hal yang perlu diajarkan kepada anak adalah, akhlak atau budipekerti atau juga dapat diakatakan sebagai karakter. Dalam keluarga, anak diajarkan seluruh aspek pengetahuan baik itu pengetahuan yang diajarkan di sekolah maupun pengetahuan yang tidak diajarkan di sekolah. orang tua merupakan guru sepanjang hayat bagi anak.

Menurut Lickona (2013:42) orang tua adalah guru moral pertama anak-anak, pemberi pengaruh yang paling dapat dapat bertahan lama. pendapat demikian dipertegas bahwa rumah berperan dalam mendukung nilai-nilai karakter anak yang diajarkan di sekolah. Sebagai Orang tua 
sudah sewajarnya mereka mengajarkan pengetahuan moral kepada anak-anaknya. Pengajaran moral kepada anak diajarkan sejak anak masih kecil. Pengajaran moral tersebut dapat dilakukan melalui hal-hal kecil.

Orang tua dapat memberikan pengajaran moral kepada anak melalui sebuah bacaan. Melalui sebuah bacaan orang tua dapat secara langsung memberikan pengetahuan moral kepada anak-anak mereka. Namun dalam memilih sebuah bacaan untuk anak, orang tua juga harus memerhatikan kualitas dari isi bacaan tersebut, serta menganalisa apakah cerita tersebut layak untuk diberikan kepada anaknya.

Cerita anak dalam koran Solopos merupakan Salah satu cerita yang dapat digunakan orang tua untuk menanamkan pendidikan karakter kepada anak. dari beberapa cerita anak yang telah dianalisis, dapat dimanfaatkan orang tua sebagai bahan penenaman moral atau karakter kepada anak. Pertama, Orang tua dapat membacakan cerita anak ketika si anak hendak tidur. membacakan cerita anak ketika si anak hendak tidur, dapat membentuk karakter anak. cerita anak pada hakikatnya mengandung nilai-nilai pesan moral yang ditujukan kepada anakanak, tentu dapat mempengaruhi karakter anak. dengan anak dibiasakan mendengar cerita-cerita yang bermoral, akan akan mampu memaphami hal-hal baik dan buruk yang harus mereka tiru dan mereka contoh.

Kedua, orang tua dapat membimbing anak ketika belajar di rumah dengan meminta anak untu membaca ceita anak ketika anak sedang tidak melakukan aktifitas apapun. saat ini sudah jarang orang tua membimbing anak untuk belajar karena orang tua terlalu sibuk dengan pekerjaan mereka sehingga ketika anak mendapat nilai jelek, orang tua memarahi anak. sebagaimana yang disamapiakn Merry Ryana (2017) dalam tayangan I'm possible bahwa orang tua itu seharusnya berjalan di depan memberi teladan, berjalan berdampingan sebagai sahabat, berjalan di belakang memberi kebebasan yang disertai rasa aman. Melalui apa yang disampaikan oleh merry ryana tersebut, kita dapat mengambil pembelajaran bahwa orang tua harus selalu membimbing perkembangan anak, jangan sampai anak kebablasan dalam pergaulannya.

\section{E. PENUTUP}

Berdasarkan hasil analisis yang telah dilakukan, cerita anak dalam koran Solopos yang terbit setiap hari minggu dapat dijadikan sebagai media pembelajaran untuk siswa sekolah dasar. Pemanfaatan cerita anak sebagai media pembelajaran tidak hanya digunakan dalam KI-KD 3.9 \& 4.9 siswa kelas 4 . Namun pada intinya cerita anak dapat digunakan sebagai media pembelajaran setiap jenjang sekolah dasar.

Alasan penggunaan cerita anak sebagai media pembelajaran dikarenakan setiap cerita anak memiliki nilai didik yang ingin diajarkan kepada pembaca. Pada cerita anak, nilai-nilai didik tersebut dapat digunakan sebagai proses penginternalisasian pendidikan karakter kepada siswa sekolah dasar. Selama ini guru kurang mengekslpor dalam pengunaan media pembelajaran. Dengan adanya ceita anak, guru dapat memanfaatkannya sebagai media pendidikan. Selain sebagai media pendidikan, cerita anak juga bermanfaat untuk mengajarkan pendidikan karakter kepada siswa. Nilai-nilai pendidikan karakter dalam cerita anak maupun semua karya sastra, dapat dimanfaatkan sebagai media untuk menginternalisasikan pendidikan karakter kepada siswa. Selain sebegai pemdia pembelajaran di sekolah, cerita anak juga dapat di gunakan sebagai media pembelajaran ketika anak di rumah. Orang tua dapat membacakan dongeng ketika anak hendak tidur, dan juga dapat dijadikan bacaan kepada anak ketika anak sedang belajar atau sedang tidak melakukan aktifitas apapun. 


\section{DAFTAR PUSTAKA}

Achmad, N. (2018). Gara-Gara Layangan. Solopos. 21 Januari 2018

Adnan, L. (2018). Peri Buku. Solopos 25 Maret 2018, p. 7.

Damayanti, D. (2014). Panduan Implementasi Pendidikan Karakter di Sekolah. Yogyakarta: Araska.

Effendi, M. (2017). Pidato Mendikbud HGN 2017 "Membangun Pendidikan Karakter melalui Keteladanan Guru." Retrieved from https://www.youtube.com/watch?v $=$ UFXKca7dp8s\&list $=$ LLNE6pCIe BWH-TmfJp91Rapg\&index $=11$

Endah, Y. (2018). Permainan Pengganti. Solopos, 18 Februari 2018, p. 7.

Habsari, Z. (2017). Dongeng sebagai pembentuk karakter anak. Bibliotika, 1(1), 21-29.

Ismawati, E. (2013). Pengajaran Sastra. Yogyakarta: Penerbit Ombak.

Kristanto, Z. (2018). Kantong Plastik Ajaib. Solopos, 4 Februari 2018, p. 7.

Latifah, R. (2018). Berburu Kinjeng. Solopos, 4 Maret 2018, p. 7.

Lickona, T. (2013). Pendidikean Karakter: Panduan Lengkap Menjadi Siswa. Bandung: Penerbit Nusa Media.

Lickona, T. (2016). Persoalan Karakter: Bagaimana Membantu Anak Mengembangkan Penilaian Yang Baik, Integritas, dan Kebajikan Penting Lainnya Jumo Abdu Wamaungo \& Jean Antunes Rudolf Zien). Jakarta: PT Bumi Aksara.

Nurgiyantoro, B. (2010). Sastra anak dan pembentukan karakter. Cakrawala Pendidikan, 2(2), 25-40.

Burgiyantoro, B. (2013). Sastra Anak: Pengantar Pemahaman Dunia Anak. Yogyakarta: Gadjah Mada University Press.
Pena, W. (2018). Prestasi Nadia. Solopos. 28 Januari 2018.

Rahmatainment. (2016). Kultum Bersama Ustadz Wijayanto:"Peran Orang Tua Dalam Mendidik Anak". Retrieved June 12, 2018, from https://www.youtube.com/watch?v $=\mathrm{SxX} 43 \mathrm{XwW}$ aoo\&index $=10 \&$ list $=$ LLNE6pCIeBWH-

TmfJp91Rapg\&t $=215 \mathrm{~s}$

Riana, M. (2017). Papa Mama Gaul Dong. Retrieved June 1, 2018, from https://www.youtube.com/watch?v $=\mathrm{UkNuiGNIGB4 \& list=LLNE6pCI}$ eBWH-

TmfJp91Rapg\&index $=36 \& \mathrm{t}=0 \mathrm{~s}$

Rokhmansyah, A. (2014). Studi dan Pengkajian Sastra. Yogykarta: Graha Ilmu.

Romadhon, M. (2018). Kado Imlek Buat Mee Lan. Solopos, 25 Februari 2018, p. 7.

Rositi. (2018). Ayo Biasakan Cuci Tangan. Solopos, 11 Maret 2018 p. 7.

Rukhayah. (2015). Pengembangan Model Pembelajaran Sastra Anak Dengan Pendekatan Kooperatif di Sekolah Dasar. UNS.

Sadiman, A. S. (2014). Media Pendidikan: Penegrtian, Pengembangan, dan Pemanfaatannya. Jakarta: Rajawali Pers.

Suhardi. (2018). Nilai-Nilai Pendidikan Karakter dalam Dongeng Putra Lakon. Lingua, 14(1).

Tarra, T. (2018). Empat Sekawan Dari Kampung Kelapa. Solopos, 4 Februari 2018, p. 7.

Wiyani, N. A. (2013). Konsep, Praktik \& Strategi Membumikan Pendidikan Karakter di SD. Yogyakarta: Ar-Ruzz Media. 